\title{
Airborne particulate matter in public transport: a field study at major intersection points in Frankfurt am Main (Germany)
}

\author{
Alexander Gerber*, Julia Bohn, David A Groneberg, Johannes Schulze and Matthias Bundschuh
}

\begin{abstract}
Background: Chronic particulate matter (PM) exposure is correlated to various health effects, even at low amounts. WHO has defined PM concentration limits as daily and annual mean values which were made legally binding in the European Union. While many studies have focused on PM concentrations in special environments, little is known about the average PM- exposure for both employees and passengers in the German public transportation system.

Methods: Particulate matter (PM10, PM2.5, PM1) - concentrations were monitored for 30 minutes at 15 different areas in Frankfurt am Main with major public traffic. Maximum and mean concentrations and, as a surrogate for the inhaled dosage, the Area Under the Curve (AUC) for 15 minutes of exposure were calculated.

Results: The WHO limits for PM10 and PM2.5 were exceeded at nearly all times and areas. Highest maximum concentrations were found at underground stations, subterranean railway stations and subterranean shopping arcades with much lower values obtained at surface points. In one measurement at a surface test point smokers who neglected the non-smoking policy could be identified as a major cause for a at least temporary strong increase of PM-load as seen in high maximum values and normal averages.

Conclusions: Subterranean areas have high particulate matter contamination exceeding WHO limits. Improvement may be achieved by increased ventilation. Subterranean shops and kiosks, being workplaces with long term exposure, should be equipped with external air supply. The non- smoking policy of the "Deutsche Bahn" for public spaces should be enforced.
\end{abstract}

\section{Introduction}

Airborne particulate matter (PM) exposure is associated with multiple health risks, such as acute and chronic respiratory problems or increased cardiovascular mortality [1-3]. A considerable part of the air pollution is caused by traffic and may contribute to PH health risks [4]. Many epidemiologic studies have illustrated traffic-associated air pollution and its deleterious effects in children and in adults [5-7]. In recent years, several studies targeted the air quality in railway stations and characterized airborne particulate matter at underground stations, inside underground- and rail wagons and at platforms [8-10].

Physical and chemical properties of particulate matter depend on their origin (e.g. combustion processes,

\footnotetext{
* Correspondence: gerber@med.uni-frankfurt.de

Institute of Occupational Medicine, Social Medicine and Environmental Medicine, Goethe-University, Theodor-Stern-Kai 7, Haus 9b, 60590 Frankfurt am Main, Germany
}

mechanical abrasion, etc.). Mechanically generated PM by abrasions of underground train vehicle chassis, brakes, wheels and rails has shown to cause different effects compared to PM from combustion in urban ambient air $[8,11]$.

The WHO has established limits of PM10 and PM2,5 concentrations which are legally binding in the EU since January 2005 (PM10) and since 2010 (PM2.5) respectively. Mean 24 hour PM10 concentrations must not exceed $50 \mu \mathrm{g} / \mathrm{m}^{3}$, mean annual values $20 \mu \mathrm{g} / \mathrm{m}^{3}$, while PM2.5 concentrations are limited to $10 \mu \mathrm{g} / \mathrm{m}^{3}$ (annual mean) and $25 \mu \mathrm{g} / \mathrm{m}^{3}$ (24 hour) [12]. Since little is known about the burden of PM10, PM2.5 and PM1 from sources like public traffic- and transport systems of a metropolis, we investigated the particulate air pollution in the public transport sector and areas of public commerce in Frankfurt am Main, including two subterranean shopping arcades integrated to underground 
stations, in a field study. The PM dosage was quantified at 15 areas of major public traffic. Exposure is quantified both as maximum and average PM concentrations.

\section{Methods}

Measurements were taken at 15 areas of major public traffic in Frankfurt am Main in August 2013; all measurements were taken for 30 minutes. The measuring points included

- 2 surface area platforms at the central railway station ("Hauptbahnhof")

- 3 bus stops at the central railway station ("Hauptbahnhof") forecourt

- 1 subterranean railway platform (Frankfurt Main Airport)

- 1 surface platform of the Frankfurt interurban train (Dreieich-Offenthal)

- 2 subterranean platforms of the Frankfurt interurban train ("Hauptbahnhof" and "Hauptwache") sub.

- 2 subterranean platforms of the Frankfurt underground railway system ("Hauptbahnhof" underground and "Hauptwache" underground)

- 3 subterranean shopping arcades linked to large underground stations (2× "Hauptbahnhof", $30 \mathrm{~m}$ and $10 \mathrm{~m}$ distance to the underground entrance, $1 \times$ "Hauptwache", $15 \mathrm{~m}$ distance to the underground entrance)

- 1 conventional surface shopping center ("MyZeil")

PM10, PM2.5 and PM1 data were recorded using a portable laser aerosol spectrometer (PLA spectrometer 1.109, Grimm Aerosol Technik, Ainring, Germany) with a 6-seconds data interval time as described for the mobile air quality study (MAQS) in inner cities [13]. Data were immediately transferred to a Lenovo laptop via data logger and stored in Windows-Excel charts. In order to prevent data discrepancies caused by strong winds as previously seen in MAQS, all surface measurements were carried out on calm days in August 2013. Statistical evaluation was performed using GraphPAD Prism 5. Maximum- und mean- PM10, PM2.5 and PM1 concentrations $\left[\mu \mathrm{g} / \mathrm{m}^{3}\right]$ were calculated for each measuring point, the area under the curve (AUC) was calculated for a period of 15 minutes [in $\mu \mathrm{g} / \mathrm{m}^{3} \times \mathrm{s}$ ].

\section{Results}

The highest average PM burden was documented at underground stations, followed by the subterranean stations of interurban- and railway trains (Table 1). Surprisingly, mean concentrations and AUC (15 minutes) of PM10, PM2.5 and PM1 at subterranean shopping arcades with access to underground stations clearly exceled any values found at surface railway stations, the central railway station forecourt bus stop or a conventional surface shopping arcade such as MyZeil. The amounts of PM detected in subterranean shopping malls proved to increase with their vicinity towards the next subway station entrance. The lowest mean concentrations and AUC were found at surface railway- and interurban train stations.

The unexpectedly high maximum concentration of PM10, PM2.5 and PM1 at the surface interurban train station "Dreieich-Offenthal" was due to cigarette smoke from two passengers standing close to our measuring device for several minutes. Notably, all subterranean

Table 1 Maximum and mean concentration of PM10, PM2.5 and PM1 $\left(\mu \mathrm{g} / \mathrm{m}^{3}\right)$

\begin{tabular}{|c|c|c|c|c|c|c|}
\hline Place & Max. $\mathrm{PM}_{10}$ & Max. $\mathrm{PM}_{2.5}$ & Max. $\mathrm{PM}_{1}$ & Mean $\mathrm{PM}_{10}$ & Mean $\mathrm{PM}_{2.5}$ & Mean $\mathrm{PM}_{1}$ \\
\hline Central Station. PI. 13 & 163 & 120 & 109 & 40 & 28 & 22 \\
\hline Central Station PI. 3 & 235 & 81 & 75 & 44 & 28 & 22 \\
\hline Dreieich-Offenthal & 567 & 549 & 545 & 46 & 31 & 28 \\
\hline Frankfurt Airport & 213 & 88 & 54 & 74 & 46 & 31 \\
\hline Central Station Sub. & 138 & 71 & 30 & 62 & 33 & 18 \\
\hline Hauptwache/Sub. & 140 & 68 & 31 & 83 & 53 & 27 \\
\hline Underground Central Station & 166 & 79 & 31 & 92 & 52 & 24 \\
\hline Underground Hauptwache & 166 & 85 & 35 & 109 & 65 & 29 \\
\hline Shopping arcade central station 1 & 121 & 57 & 43 & 44 & 24 & 17 \\
\hline Shopping arcade Hauptwache & 97 & 47 & 26 & 61 & 31 & 21 \\
\hline Shopping arcade central station 2 & 324 & 63 & 54 & 73 & 38 & 31 \\
\hline Central Station Forecourt 1 & 135 & 127 & 119 & 35 & 22 & 16 \\
\hline Central Station Forecourt 2 & 212 & 206 & 201 & 37 & 23 & 19 \\
\hline Central Station Forecourt 3 & 230 & 120 & 113 & 50 & 27 & 21 \\
\hline Myzeil (Shopping Center) & 201 & 46 & 32 & 51 & 30 & 26 \\
\hline
\end{tabular}




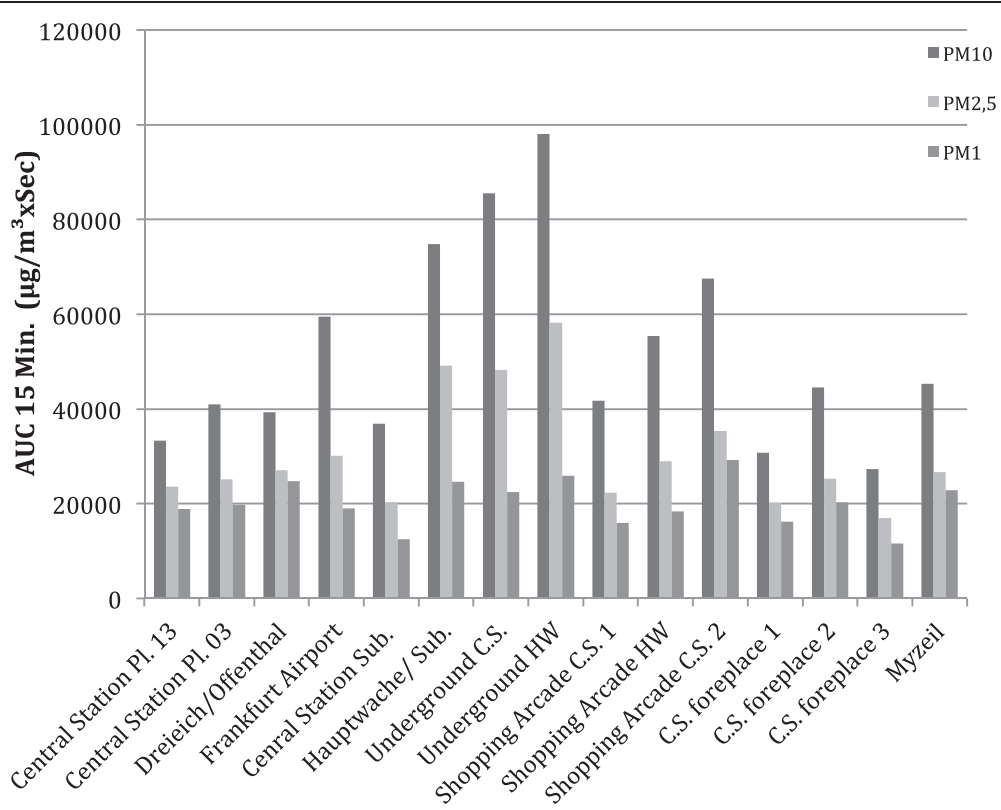

Figure 1 AUC of the PM10-, PM2.5- and PM1- load at each measuring point. The AUC was calculated for a duration of 15 minutes assumed as a realistic time for passengers changing connections.

points show much higher AUC-PM values than any surface measuring point, despite air conditioning- and ventilation at all subterranean shopping arcades and underground stations. The observed outlying maximum levels of PM with a lower effect on the AUC (e.g. Dreieich-Offenthal, Table 1) are mostly caused by smokers who ignored the non- smoking policy, or were caused by a tourist bus waiting with running engine (central railway station forecourt, Table 1).

Table 1 summarizes the maximum- and mean PM10, PM2.5 and PM1 concentrations of each measuring point.

Figure 1 illustrates the relation between PM10, PM2.5 and PM1 AUC values at each measuring point. The dose for waiting, traveling or shopping persons at each of the locations was calculated as "Area Under the Curve" (AUC); for comparison an average of 15 minutes was assumed for people changing trains. As can be seen the PM composition at these areas was similar, with slight differences between the PM fractions. Whereas the highest AUC for PM10 coincided with the PM2.5 value the highest PM1 value was found in a shopping arcade. Also the large variation for PM10 values is not mirrored in PM1 values and only partially preserved in PM2.5 values (Figure 1, Table 2).

Table 2 summarizes the AUC-data of PM10, PM2.5 and PM1 at each measuring point, calculated for 15 minutes.

\section{Discussion}

In this field study, maximum permissible values for PM10 and PM2.5 as defined by the WHO have been exceeded at nearly all measuring points of public mass transit, when the values are extrapolated to daily or annual mean values. Underground stations, subterranean railway platforms and subterranean shopping arcades have been identified as places with the highest PM- exposure. Although our data were sampling individual places and days, the analysis was executed as a field study. There are no indications that the results were

Table 2 AUC of PM10, PM2.5 and PM1 $\left(\mu \mathrm{g} / \mathrm{m}^{3} \times \mathrm{sec}\right.$.) calculated for each measuring point referring to 15 minutes

\begin{tabular}{llll}
\hline Ort & PM $_{\mathbf{1 0}}$ & $\mathbf{P M}_{\mathbf{2 . 5}}$ & $\mathbf{P M}_{\mathbf{1}}$ \\
\hline Central Station. Pl. 13 & 33274 & 23579 & 18824 \\
Central Station PI. 3 & 40958 & 25157 & 19825 \\
Dreieich-Offenthal & 39353 & 27070 & 24767 \\
Frankfurt Airport & 59460 & 30071 & 18970 \\
Central Station Sub. & 36927 & 20351 & 12480 \\
Hauptwache/Sub. & 74816 & 49112 & 24686 \\
Underground Central Station & 85582 & 48295 & 22439 \\
Underground Hauptwache & $\mathbf{9 8 0 2 5}$ & $\mathbf{5 8 2 4 9}$ & $\mathbf{2 5 8 9 4}$ \\
Shopping arcade central station 1 & 41805 & 22342 & 15961 \\
Shopping arcade Hauptwache & 55400 & 29026 & 18310 \\
Shopping arcade central station 2 & 67485 & 35413 & $\mathbf{2 9 2 4 3}$ \\
Central Station Forecourt 1 & 30756 & 20099 & 16240 \\
Central Station Forecourt 2 & 44610 & 25223 & 20325 \\
Central Station Forecourt 3 & 27363 & 16976 & 11626 \\
Myzeil (Shopping Center) & 45277 & 26633 & 22868 \\
\hline
\end{tabular}

The data in bold represent the highest measured data of their group. 
flawed by the time of the day or specific high exposure conditions; thus it is expected that the results can be transferred also to full time employees working under these conditions. Among the clientele with high exposure are e.g. shop assistants in subterranean stations and shopping arcades, cleaning workers or maintenance personnel.

Most of the larger subterranean stations are equipped with their own air supply; however, -our data indicate room for improvement.

\section{Conclusion}

Each shop or kiosk located in a subterranean station should get its independent fresh air supply. From individual measurements it was also evident that smoking is a major cause of PM burden, causing a temporary increase of PM10, PM2.5- and PM1 concentrations. Hence smoking areas should always be designed with sufficient distance to working spaces, and the general non-smoking policy in public areas should be enforced.

\section{Competing interest}

The authors declare that they have no competing interests.

\section{Authors' contributions}

DAG, JS and AG made substantial contributions to the conception and design of the review, JB and MB acquisred the data and have been involved in drafting and revising the manuscript. All authors have read and approved the final manuscript.

Received: 7 February 2014 Accepted: 14 March 2014

Published: 9 April 2014

\section{References}

1. Kappos AD, Bruckmann P, Eikmann T, Englert N, Heinrich U, Hoppe P, Koch E, Krause GH, Kreyling WG, Rauchfuss K, Rombout P, Schulz-Klemp V, Thiel WR, Wichmann HE: Health effects of particles in ambient air. Int J Hyg Environ Health 2004, 207(4):399-407. doi:10.1078/1438-4639-00306.

2. Brook RD, Rajagopalan S, Pope CA 3rd, Brook JR, Bhatnagar A, Diez-Roux AV, Holguin F, Hong Y, Luepker RV, Mittleman MA, Peters A, Siscovick D, Smith SC Jr, Whitsel L, Kaufman JD: Particulate matter air pollution and cardiovascular disease: an update to the scientific statement from the American Heart Association. Circulation 2010, 121(21):2331-2378. doi:10.1161/CIR.0b013e3181dbece1.

3. Weichenthal SA, Godri-Pollitt K, Villeneuve PJ: PM2.5, oxidant defence and cardiorespiratory health: a review. Environ Health 2013, 12:40.

4. Hoek G, Brunekreef B, Goldbohm S, Fischer P, van den Brandt PA: Association between mortality and indicators of traffic-related air pollution in the Netherlands: a cohort study. Lancet 2002, 360(9341):1203-1209. doi:10.1016/ s0140-6736(02)11280-3.

5. Duhme H, Weiland SK, Keil U, Kraemer B, Schmid M, Stender M, Chambless $L$ : The association between self-reported symptoms of asthma and allergic rhinitis and self-reported traffic density on street of residence in adolescents. Epidemiology 1996, 7(6):578-582.

6. Weiland SK, Mundt KA, Ruckmann A, Keil U: Self-reported wheezing and allergic rhinitis in children and traffic density on street of residence. Ann Epidemiol 1994, 4(3):243-247.

7. Edwards J, Walters S, Griffiths RK: Hospital admissions for asthma in preschool children: relationship to major roads in Birmingham, United Kingdom. Arch Environ Health 1994, 49(4):223-227. doi:10.1080/ 00039896.1994 .9937471$.

8. Loxham M, Cooper MJ, Gerlofs-Nilland ME, Cassee FR, Davies DE, Palmer MR, Teagle DA: Physicochemical characterization of airborne particulate matter at a mainline underground railway station. Environ Sci Technol 2013, 47(8):3614-3622. doi:10.1021/es304481m.
9. Assimakopoulos MN, Dounis A, Spanou A, Santamouris M: Indoor air quality in a metropolitan area metro using fuzzy logic assessment system. Sci Total Environ 2013, 449:461-469. doi:10.1016/j. scitotenv.2012.12.043.

10. Park DU, Ha KC: Characteristics of PM10, PM2.5, CO2 and CO monitored in interiors and platforms of subway train in Seoul, Korea. Environ Int 2008, 34(5):629-634.

11. Janssen NA, Yang A, Strak M, Steenhof M, Hellack B, Gerlofs-Nijland ME, Kuhlbusch T, Kelly F, Harrison R, Brunekreef B, Hoek G, Cassee F: Oxidative potential of particulate matter collected at sites with different source characteristics. Sci Total Environ 2013, 472C:572-581. doi:10.1016/j. scitotenv.2013.11.099.

12. WHO: Air quality and health, Fact sheet $N^{\circ} 313$. 2011. [http://www.who.int/ mediacentre/factsheets/fs313/en/] Accessed 04.01.2014.

13. Uibel S, Scutaru C, Mueller D, Klingelhoefer D, Hoang DM, Takemura M, Fischer A, Spallek MF, Unger V, Quarcoo D, Groneberg DA: Mobile air quality studies (MAQS) in inner cities: particulate matter PM10 levels related to different vehicle driving modes and integration of data into a geographical information program. J Occup Med Toxicol 2012, 7(1):20. doi:10.1186/1745-6673-7-20.

doi:10.1186/1745-6673-9-13

Cite this article as: Gerber et al:: Airborne particulate matter in public transport: a field study at major intersection points in Frankfurt am Main (Germany). Journal of Occupational Medicine and Toxicology 2014 9:13.

\section{Submit your next manuscript to BioMed Central and take full advantage of:}

- Convenient online submission

- Thorough peer review

- No space constraints or color figure charges

- Immediate publication on acceptance

- Inclusion in PubMed, CAS, Scopus and Google Scholar

- Research which is freely available for redistribution 